\title{
Processes for Ex-ante Evaluation of IT Projects - Case Studies in Brazilian Companies
}

\author{
Fernando José Barbin Laurindo and Renato Oliveira Moraes \\ Production Engineering Department of Polytechnic Engineering \\ School - University of São Paulo, São Paulo, Brazil and \\ Federal University of Ouro Preto. Ouro Preto \& FEAD - Business \\ Studies College of Minas Gerais - Belo Horizonte, Brazil
}

\author{
fiblau@usp.br renato.moraes@perceptron.com.br
}

\begin{abstract}
In the highly competitive nowadays markets, many companies actions assume the project form. In special, Information Technology (IT) projects assume great importance, enabling the dynamic actions that organisations need (Porter, 2001; Tapscott, 2001). However, IT applications assume different roles, from operational support to strategic, according to companies' strategies and operations, besides the peculiarities of the industry in which they compete (McFarlan, 1984; Porter \& Millar, 1985). According to this role (appraised by McFarlan's Strategic Grid), ex-ante evaluation practices for selecting IT projects to be implemented can vary (Jiang \& Klein, 1999). The objective of this paper is to analyse practices for selecting IT projects in Brazilian companies classified in different quadrants of the Strategic Grid and to observe any differences in ex-ante evaluation practices among them. The adopted methodological approach was qualitative research, more specifically case study (Claver, Gonzalez \& Llopis, 2000; Yin, 1991) performed in four companies.
\end{abstract}

Keywords: Information Technology, IT projects, Project Management, IT effectiveness, IT Strategy, Ex-ante Evaluation, Project Selection

\section{Introduction}

The current competitive scenery is characterised by the dynamism of business operations. As a consequence, many plans assume the form of projects, which compete for scarce and disputed resources. Among these projects, Information Technology (IT) projects can play a very important role, by enabling dynamic actions that organisations need to stay competitive (Porter, 2001; Tapscott, 2001). Therefore, IT projects management can present strong links with companies operations and strategies.

Material published as part of this publication, either on-line or in print, is copyrighted by the Informing Science Institute. Permission to make digital or paper copy of part or all of these works for personal or classroom use is granted without fee provided that the copies are not made or distributed for profit or commercial advantage AND that copies 1 ) bear this notice in full and 2) give the full citation on the first page. It is permissible to abstract these works so long as credit is given. To copy in all other cases or to republish or to post on a server or to redistribute to lists requires specific permission and payment of a fee. Contact Publisher@InformingScience.org to request redistribution permission.
Although some authors argue about the actual benefits of IT applications, like Carr (2003, 2005), decisions concerning which IT applications should be implemented are still important for operations and, in many situations, for business strategy (Brynjolfsson \& Hitt, 1998). It is largely discussed in the literature that IT role in organisations can vary from simple administrative support to a strategic position (Farrel, 2003; Henderson 
\& Venkatraman, 1993; McFarlan, 1984). Internet has increased this potential and also the reach and impact of IT applications, especially in the most competitive markets (Porter, 2001).

Several authors have studied the strategic impact of IT applications (specially information systems - IS), both on single firms and on industries. The Strategic Grid is a widely known model proposed by McFarlan (1984), which allows the visualization of the relationship between IT strategy and the business strategy, considering both present and future situations. Henderson \& Venkatraman (1993) pointed out the importance of the alignment among IT and business strategies, as well as they analysed the different forms for such alignment occurs.

Thus, there is a need for an appropriate IT management that should include adequate evaluation and selection of which IT projects would be implemented and if internal resources and competences are sufficient for these projects or if it is necessary to outsourcing them.

The way the selection process is performed in different companies present differences regarding the extension of its formalisation and also the criteria adopted to choose and to prioritize possible alternative solutions for implementation. However, the form of these selection and prioritisation processes depends on the role that IT carries out in the organisations. Jiang \& Klein (1999) studied how companies classified in different quadrants of Strategic Grid select their IT projects, and they found significant distinctions.

McFarlan (1981), in another work, analysed how to select new IT applications projects considering individual project risks, as well as the risks of a project portfolio. Thus, the companies would decide just based on the analysis of each project (Laurindo, Carvalho, \& Shimizu, 2003) or taking into account a group of alternatives of new possible IT projects, i.e., considering IT projects portfolio (Moraes \& Laurindo, 2003).

The adopted methodological approach was qualitative research, more specifically case study (Claver, Gonzalez \& Llopis., 2000; Yin, 1991) performed in four companies.

The aim of this paper is to analyse ex-ante evaluation practices for selecting IT projects in companies in activity in Brazil. Besides, the research searches for differences among these practices, although there has been an intense outsourcing of IT activities, as well as a wide use of 'packages' and standardized software.

In order to investigate the concepts above and the central question "How companies selects IT projects", the adopted methodological approach was a multiple case study (Claver, Gonzalez \& Llopis, 2000; Yin, 1991).

Four companies were selected for this study. Each of these companies would be classified in different quadrants of McFarlan's Strategic Grid, in a preliminary analysis. Besides, companies should present an important set of IT projects, as well as regular processes for project management. The information was obtained through semi-structured interviews with different players of the company, including IT professionals and the users from different hierarchical levels.

\section{Information Technology Projects Strategic Impacts}

The role of IT in organisations has changed in many ways along the years. Initially, hardware and software imposed many restrictions to the spectrum of possible IT applications, limiting them to more structured and less complex situations, like, typically, payroll, stock control and accounting. However, technological advances gradually brought new and far more including possibilities (Zwass, 1998). On the other hand, the wider range of these possibilities also brought greater difficulties on the decisions about which projects should be implemented (Laudon \& Laudon, 2004; Moraes \& Laurindo, 2003). 
At this point, efficiency and effectiveness concepts are very useful for understanding IT role in organisations (Laurindo, 2002).

Efficiency is associated to the use of resources, while effectiveness is associated to achieving goals and objectives and with requirements satisfaction. Efficiency is related to internal aspects of IT management and the appropriate use of resources, while effectiveness confronts results of IT applications with their impact on business operations and also in business strategy and organisational structure (Laurindo et al, 2003). IT effectiveness means to use it to leverage company business competitiveness.

In the discussion about IT effectiveness, it is necessary to understand several different approaches for analysing the strategic role of IT in the organisations, in order to build a broad vision of this role.

One of the first proposals to solve the problem of choosing and prioritizing IT projects was the Critical Success Factors (CSF) method developed by Rockart (1979) and that is still widespread used nowadays. This method aimed especially management and executive information systems and it was based on the definition by top executives of their current needs, expressed by the CSF. Rockart defines CSF as the areas where satisfactory results 'ensure successful competitive performance for the organization'. This author states that CSF prime sources are structure of industry, competitive strategy, industry position, geographic location, environment and temporal factors. Although primarily conceived for information systems design, this method had an important impact on managerial and strategic planning practices. It is usual to define CSF for different functions of the company, like marketing CSF, manufacturing CSF, projects CSF, among others.

McFarlan (1984) proposed the Strategic Grid that allows understanding the relationship between IT and business strategies. This model analyses the impacts of IT existent applications (present situation) and of IT applications portfolio (future situation), defining four boxes (or quadrants), each one representing one possible role for IT in the enterprise: 'Support', 'Factory', 'Turnaround' and 'Strategic' (Figure 1).

- 'Support': IT has little influence in present and future IT application will not affect company strategies.

- 'Factory': existent IT applications are important for company's operations success, but there is no new strategic IT application planned for the future.

- 'Turnaround': IT is changing from a situation of little importance ('support' box) to a more important status in business strategy.

- 'Strategic': IT is very important in business strategy in the present and new planned IT applications will maintain this strategic importance in the future.

In order to assess these strategic impacts of IT, McFarlan proposed to analyse IT applications effects on the five competitive forces (Porter, 1979).

Porter (1979) emphasizes the importance of positioning a firm in its industry, in order to achieve a sustainable competitive advantage through the choice of one of three alternative generic strategies: cost leadership, differentiation and focus. Meanwhile, the competitiveness of an industry results from the interaction of five competitive forces: buyers bargain power, suppliers bargain power, threat of substitute products or services, threat of new entrants and rivalry among existent competitors.

According to McFarlan, IT can alter the balance of the competitive forces of an industry, since it can establish barriers to the entrance of new competitors, it can change the relationship among suppliers and customers, it can enlarge the basis of potential suppliers or strengthening existent relationships and finally it can create new businesses. 


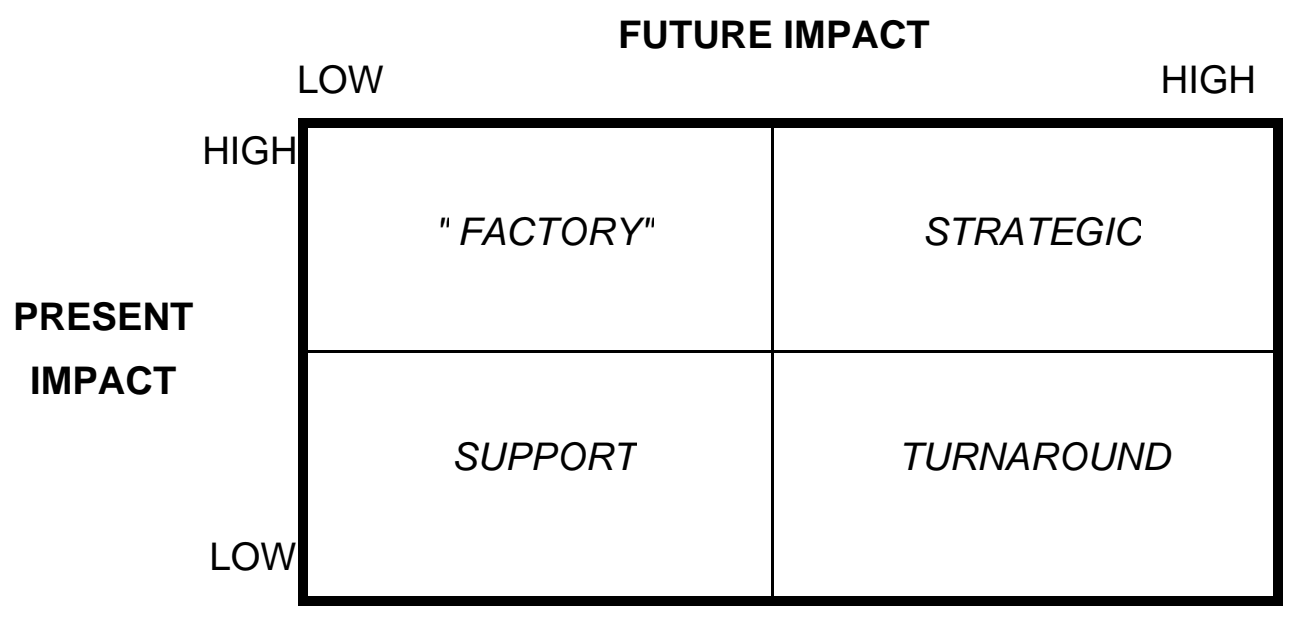

Figure 1: Strategic Grid, strategic impact of IT applications (adapted from McFarlan, 1984)

Nolan \& McFarlan (2005) have recently updated the Strategic Grid, changing the two "axis" to "Need for Reliable IT" (instead of "Present Impact") and "Need for new IT" (instead of "Future Impact"). These authors stated that companies in "Support" and "Factory" quadrants adopt a Defensive approach regarding IT, meanwhile companies in "Turnaround" and "Strategic" quadrants can be considered Offensive in IT use.

Henderson \& Venkatraman (1993) proposed the "Strategic Alignment Model", which analyses IT strategic importance in the companies. This model is based not only on company internal factors (infrastructure) but also on external factors (strategy).

Therefore, according to this model, in order to plan IT, four important factors should be considered: (i) business strategy; (ii) IT Strategy; (iii) organizational infrastructure and processes; (iv) infrastructure of information systems and processes.

The basic premise of the Strategic Alignment Model is that an effective IT requires a balance between the decisions in all these four factors. An important novelty of this model is that it considers that IT strategy can change a company's business strategy, when usually business strategy is considered as the starting point for IT planning.

Since external factors are constantly changing, this planning should be a continuous process. If the company does not follow these changes, it can be in serious disadvantage in the fierce competition of nowadays markets. That is particularly true when a new technology is adopted by almost all companies of an industry; in this situation, this technology does not represent a competitive advantage for their users but is a clear disadvantage factor for non users (Luftman, Lewis \& Oldach, 1993).

Henderson \& Venkatraman (1993) and Luftman et al. (1993) presented four main perspectives of strategic alignment, considering business strategy or IT Strategy as driver of this process, as follows:

\section{I - Strategy Execution}

Business strategy directs choices of organizational infrastructure and, as consequence, the decisions about IT infrastructure; it corresponds to the classic model of hierarchical vision of strategic management. 


\section{Business strategy $\Rightarrow$ Business Infrastructure $\Rightarrow$ IT Infrastructure}

\section{II - Technology Transformation}

Technological leadership is the basis for competing. The implementation of business strategy depends on a new IT Strategy, which demands for an appropriate IT infrastructure and processes

Business strategy $\Rightarrow$ IT Strategy $\Rightarrow$ IT Infrastructure

\section{III - Competitive Potential}

Business Strategy and business infrastructure are consequences of the adoption of a new IT Strategy, capable to bring impacts in products and services, influencing strategy and relationships in the market.

\section{IT Strategy $\Rightarrow$ Business Strategy $\Rightarrow$ Business Infrastructure}

\section{IV - Service Level}

The aim of this perspective is to provide world class Information System services to business infrastructure. IT performance criteria are based on the satisfaction of IT users.

\section{IT Strategy $\Rightarrow$ IT Infrastructure $\Rightarrow$ Business Infrastructure}

McFarlan (1981) analysed the selection process of new IT applications projects considering the risks associated with each project and also the risks of projects portfolio. These risks encompass costs, time, technical performance, overestimation of IS benefits and incompatibility of hardware and/or software for the IS.

Selection of IT projects was also studied by Jiang \& Klein (1999), which took into consideration the four different possibilities of the Strategic Grid. Enterprises classified in the 'strategic' and 'turnaround' quadrants usually are more prone to assume risks and have more rigorous controls for IT projects. On the other hand, enterprises classified as 'support' consider costs as the primary criterion for selecting and conducting IT projects.

Moraes \& Laurindo (2003) presented a procedure for building a portfolio IT development projects, considering the strategic impact of these projects and an evaluation of the risks associated to each project. It uses a typology of projects that supports this analysis and it also provides elements for building a portfolio that balances IT efficiency and effectiveness demands in the organization.

Several authors proposed methods based on portfolio concept for ex-ante evaluation or selection of IT projects, as Bedell (1985), Luehrman, (1998a, 1998b) and Tjan (2001). Khalifa et al. (2001) affirmed that there is a consensus that there is no IT evaluation method that can be applied in all situations. Farbey et al. (1993) suggested that the evaluation presents better results when an appropriate method is applied to an also appropriate organizational context.

The evaluation of IT projects should consider, simultaneously, efficiency (use of resources) and effectiveness (obtaining results for the organization) aspects, and also the analysis of their risks. These criteria are very important in highly competitive markets of the globalised economy. In this paper, practices adopted by the companies to evaluate IT projects to be implemented are investigated, observing the relationship of the concepts described in this item.

\section{Methodology}

As previously mentioned, the aim of this paper is to analyse ex-ante evaluation practices for selecting IT projects in companies in activity in the Brazilian market and that can be classified in different quadrants of the Strategic Grid. The investigation searches for differences among these 
companies, although there has been an intense outsourcing of IT activities, as well as the use of 'packages' and standardized software (as ERP - Enterprise Resource Planning - Systems).

In order to investigate the concepts above and the central question "How companies evaluate and select new IT projects ", the adopted methodological approach was qualitative research, more specifically a multiple cases study (Claver et al., 2000; Yin, 1991).

Based on the discussion about project selection practices in companies classified in different quadrants of Strategic Grid, specially by MFarlan (1984); Jiang and Klein (1999), Nolan and McFarlan (2005), the following propositions should be investigated:

- (p1) companies classified in quadrants "Support" and "Turnaround" of the Strategic Grid should present less systematic procedures to select IT projects;

- (p2) there is a bigger involvement of business personnel in IT projects selection in companies classified in the "Strategic" and "Factory" quadrants of the Strategic Grid;

- (p3) criteria of strategic nature are more frequently used to select IT projects in companies classified in the "Strategic" and "Turnaround" quadrants" of the Strategic Grid.

The criteria for selecting the companies to be studied were the following:

- Business and operations in Brazilian market;

- An important portfolio of IT projects;

- Regular processes for project management;

- Each of these companies should be classified in different quadrants of McFarlan's Strategic Grid, in a preliminary analysis.

This preliminary classification in the Grid was based on a brief analysis of secondary data about the companies and on short contacts by email and/or telephone, regarding the present importance of IT applications and the plans for new significant projects. During the case study, these classifications were re-analysed based on the collected data.

Data was obtained through semi-structured interviews with different players of the company, including IT professionals and the users from different hierarchical levels. The main points of the questionnaire used in these interviews are the following:

- Company Characteristics: businesses, products, competitive strategy, organisational structure, operations, presence of business unit, recent results, industry competitive forces.

- IT organisation: IT position in the company hierarchy, IT history in the company

- IT projects selection and evaluation in the company: formal methods for evaluating IT projects, decision making process regarding IT issues, IT projects risk analysis process, IT project financial viability process, IT committee existence, IT discussion forums, IT company position in relation to main competitors, IT in the organisation in the vision of IT professionals, IT in the organisation in the vision of users, existence of periodic meetings among IT and user areas, process for building IT projects portfolio.

- Critical Success Factor identification: is there formal CSF defined for the company, definition of CSF if they were not previously defined relationship of CSF with strategic objectives.

- Strategic Grid: identification of the main existent IT applications, identification of the main planned IT applications.

- Strategic Alignment Model: identification of the perspective relative to company situation, importance of new technologies, definition of the driver of IT implementation processes. 
- IT importance for competitiveness: strategic, operational, present and future

Four Brazilian companies were selected for this study. Each of them was classified in different quadrants of McFarlan's Strategic Grid, in the preliminary analysis (see Figure 2). Their characteristics were:

- Case A: a company operating in the transport of medical and pharmaceutical products.

- Case B: a clothes retailer that, since some years ago, made significant IT investments that have been very important for its competitiveness.

- Case C: a worldwide supplier operating in Brazil in distribution, transportation and logistics services.

- Case D: a worldwide manufacturer (also operating in Brazil) of components for automobile industry.

\section{FUTURE IMPACT}

HIGH LOW

PRESENT

IMPACT

\begin{tabular}{|c|c|}
\multicolumn{2}{c|}{ HIGH } \\
\cline { 2 - 3 } HIGH & LOW \\
\hline CASE B & CASATEGIC C \\
\hline SUPPORT & TURNAROUND \\
CASE A & CASE D \\
\hline
\end{tabular}

Figure 2. Preliminary classification of studied companies in McFarlan's Strategic Grid

\section{Case Studies}

\section{Case A}

Case A is a company operating in the transport of pharmaceutical and medical products. It is part of a conglomerate of companies in medical and, mainly, pharmaceutical industries. It should be highlighted that nowadays, most of its revenue comes from services provided to companies of the same group.

Its generic competitive strategy is focus with differentiation (to provide service to pharmaceutical companies). The provided services can be considered complex, because its fleet is specially equipped to transport this type of products, the vehicles present special devices for the shipment of sensitive and fragile materials. The differential of the company relies on its great operational specialisation to carry out this function. 
The critical success factors of this company are:

- Operational excellence and services reliability;

- Integrated business in order to offer a complete array of services as a logistics operator.

- High service level, minimizing rates of claiming, misleading and mishaps.

Although operating in an industry in which IT has been very important, IT area of company A presents little impact in the business strategic planning. It is limited to support company operations, providing managerial tools, hardware maintenance and implementation of projects that automate operations and to enhance stronger linking with branches and partners.

Thus, IT applications have the purpose of improving operations of other departments and areas of this company. There are no plans of new IT applications that could change this situation by bringing significant strategic impacts. Therefore, this company can be classified in "Support" quadrant. In other words, IT applications have low strategic influence as much in the present as in the planned future.

The vision is that IT should supply the necessary support to operations in order to achieve company strategic objectives. This indicates that the perspective of strategic alignment, as proposed by Henderson and Venkatraman (1993), would be "Strategy Execution".

The selection of IT projects is just a reaction to IT operational needs, and the basic performance criterion is based on financial factors, reflecting a vision of IT as cost and not as investment.

In company A, there is an intense sharing of risks and responsibilities between IT and business. The IT area is demanded to offer support for implementation of projects that look for achieving goals stated by stakeholders and top management during strategic planning phase. Risks and responsibilities are strictly controlled by top management. IT projects are considered as part of other projects involving the main activities end of this company. There is a rigid control of IT projects regarding costs and time for implementation. Projects with high risk and out of strategic planning scope are simply discarded.

\section{Case B}

Company B has operated since the 40's as clothing retailer, especially women's wear, but also men's and children's wear and accessories for Bed, Tableware \& Bathing. It presents a constant concern to be updated to market trends and it is always innovating as a strategy for growing.

The company is quite aware of fashion tendencies, by researching new releases in the whole world, keeping in touch and negotiating with both national and foreigner suppliers, specially those with notorious brands.

It holds approximately 150 stores and three distribution centres, dispersed through different Brazilian regions.

Purchases from their main suppliers are made in its central office in São Paulo, since supply policy privileges centralisation. This supply policy allows buying well in order to be able to sell their products at more accessible prices, which is considered fundamental in its adopted competitive strategy.

From the point of vision of the CIO (Chief Executive Officer, main IT executive) and confirmed with businesses executives, the critical success factors for company B would be:

- Relationship with suppliers - it is important in order to the company be able to implement one of their main strategies: competitive prices. 
- Following fashion tendencies (world and national) since in clothing business this is a crucial aspect, with emphasis in following the main European tendencies, which always are a season ahead of national fashion;

- Products Disposition in the stores - clothes retailers need to have their products appropriately available and presented to the consumers.

Since Company B has looked for integration among the several company areas in the last years, the importance of IT role has increased. IT role passed from just a support area to a strategic factor, operating closely and in alignment with its business. IT is subordinated to the Executive Vice-President (in the same hierarchical level of another areas, like sales and marketing), and its executives considered that it is fundamental that IT teams understand company business and not only technical aspects, so that IT can be strategically aligned with company objectives.

In the last years, company B made significant IT investments that impacted positively its competitiveness and that placed this company in advantage in IT utilisation in comparison to their competitors. The focus was to support business needs, looking for, when necessary, forms to develop or to acquire technologies that the firm do not dominate. So, the IT and business strategic alignment started from this moment and on and was an important mark to the company since IT had changed its role and also users perception of this importance had modified. Another important mark was the great investments in e-commerce, with over than 300 products sold through its Virtual Store.

Thus, in this process, this company built a much more comprehensive IS infrastructure, effective and efficient, capable to monitor and to support properly the critical success factors mentioned above. Decisions concerning to IT issues passed to be taken in partnership between IT and users areas, with focus in possible strategic impacts, which shows that IT started to play a far more important role than merely support.

After this qualitative breakthrough, there has been no forecast of new IT applications with strategic impact in the planned future. This situation confirms company classification in the "Factory" quadrant of the Strategic Grid.

Many of the presently available technologies in the company are provided by outsourcing. Although this practice may cause some dependence, it provides agility to be the pioneer in the adoption of new IT solutions in its industry. Considering this situation, this company can be classified in the "Technology Transformation" perspective, according to the typology of Henderson and Venkamatran (1993).

It must he emphasised that IT projects portfolio is quite diversified in this company, varying from projects that demand only one IT professional allocated in partial time until big projects that involve several areas and a full time dedication team. IT projects are selected by a committee composed by members from IT and users areas; this composition can vary according to the nature of the projects in evaluation. This committee evaluates the proposals without following a specific procedure. The result from the evaluation process indicates to the top management and to the shareholders which projects should be considered critical.

In cases of adoption of new technologies, the company hires specialized consultancies to aid in the search for solutions and in the evaluation of the proposals. Finally, the company has demonstrated the first initiatives in terms of implementation of concepts about IT governance, although without formal procedures, focusing in the guarantee of the consistence of results of the projects with their proposed objectives. 


\section{Case C}

Case C is a worldwide supplier (also operating in Brazil) of distribution and logistics services. It can be considered one of the great logistic operators in the world, with special emphasis in its performance in foods industry. It is a 50 years old company that operates in 10 different countries (including Brazil) through 29 distribution centres. It provides among others services: customers stocks planning, transport, storage and logistic planning.

Its global strategy concentrates in the following objectives: to be considered the best supplier by its customers; to develop a world class organization; to promote businesses growth; to obtain effective results. It is separated in 4 business areas:

- corporate services (Human resources, IT and Finances);

- a joint venture with another multinational company that work with commodities, offering services for restaurants, hotels, hospitals and bars;

- a provider of storage, transports and distribution services, besides consultancy and support in Supply Chain Management; and

- a business area specifically dedicated to assist its main customer worldwide.

IT area, therefore, is subordinated to "Corporate Services", but supports all other business areas.

IT has been one of the greatest integration factors, a differentiation enabler and consequently a factor of company's competitiveness increase in the logistics market. Company $\mathrm{C}$, in fact, has been highlighted in these aspects, and has been considered benchmark not only in its industry. In the vision of company IT users, there is a clear relationship between IT and company business. Investments in IT allowed a larger speed in providing services to its customers, as well as they make possible a better stocks management and optimization of distribution routes.

In this context, critical success factors for this company can be considered the following:

- Capacity for changing: flexibility, innovation, proactive posture and disposition to assume risks.

- To act as only one company: thought and global performance and solid help among all to obtain success.

- Relationships: durable relationships with respect, integrity and mutual trust with employees, suppliers and communities.

- Execution: accomplishment of agreements terms.

Nowadays, existent IT applications present, as previously mentioned, big strategic importance for this company. There is a great dependence on an integrated information system that allows providing safe and efficient services, seeking to optimize resources use and to maximize information flow along Supply Chain. There is an expectation that new IT applications would be implemented, fundamentally based on the Internet potential, that would allow a growing and increasingly richer information flow between customers and suppliers.

In company $\mathrm{C}$ industry, many firms constantly look for costs reduction and customers' pressure for more aggregated value services; this indicates that new IT applications will also play a significant strategic impact in the future. Thus, this company can be classified in the "Strategic" quadrant, since IT performance in the company should be aligned with organization goals, due to its strategic role.

Although there are constant technology changes applicable to this industry, this company privileges internal development of IT applications. 
IT structure and strategy satisfy the necessary requirements in order to put strategy in practice; this indicates that, nowadays, this company follows the " Strategy Execution" perspective, according to Henderson and Venkamatran (1993) model. IT is strongly guided by company business strategy and IT management is the implementer of the formulated strategy, enabling alternatives and allowing monitoring of organization strategic objectives.

IT area makes monthly meetings with Business Executives in order to discuss on going and planned IT projects. However, there is no formal method for evaluating IT applications to be implemented. The process usually includes an analysis of projects alignment with company strategy and also return on investment (ROI) estimates. So, decisions concerning IT applications are driven by company business strategy. Usually projects are developed according to costs estimates, although their duration are not seldom underestimated.

\section{Case D}

Case D is a worldwide supplier parts to automobile industry. It belongs to a multinational corporation that operates in different industries: building materials, glasses, plastics and industrial ceramics. This group is present in 46 countries, with more than 1.200 companies and 171.000 employees. In Brazil, this group has 11.000 employees in 43 dispersed industrial units in 36 cities of 8 Brazilian states.

Two great business areas exist in company D: (i) large scale production of original parts to automobile industry and (ii) replacement market. The first is subjected to high time and quality demands. The second business area faces a larger competition, with diversity of brands and competitors.

The critical success factors for the company D, according to its executives, are:

- Process Technology;

- Integration to the supply-chain;

- Quality;

- Original parts markets: on time deliveries, with the required quality and in the right quantity;

- Replacement market: availability of demanded products.

IT area is subordinated to financial area, providing support to business development

After the implementation of an ERP system that allowed the global integration of the company, this company started to be more dependent on their information systems to compete successfully.

However, there is a distinction of this dependence on IT in each of the two business areas. In original pieces market, all the complexity of necessary information for a repetitive intermittent production was already reached and stabilized; so IT role can be classified in "Factory" quadrant.

On the other hand, in replacement market, that was first analysed for the preliminary classification, there is a demand for a increasingly growing integration with the various customers and for flexibility and promptness in service providing, which makes IT a source of differentiation and fundamental for the success in this kind of operations. These IT applications are still being planned, because nowadays IT plays just a support role. This change in the near future allows characterizing IT role for this business area in the "Turnaround" quadrant, as previously indicated.

Once top management has established strategies and business objectives in both business areas, IT should provide the required applications and services. Therefore, company IT does look for technological leadership or the creation of new business forms, but to supply to each unit the re- 
quired tools to each respective strategy. In this way, strategic alignment in this company is classified in the "Strategy Execution" perspective.

There is none systematic forum to discuss aspects of strategic alignment between IT and business. However, it is not uncommon that IT area participate in meetings that discuss strategic issues, because users understand IT strategic role as a crucial factor.

IT projects selection is made through a financial viability evaluation executed by IT area. Besides, there is an analysis that compares advantages and disadvantages of each proposal and a calculation of implementation and maintenance costs involved. Frequently, projects are discussed additionally through business cases. After the decision for the implementation, the amount of resources is discussed that would be made available for the approved projects. Project teams can include professionals from user areas, besides IT people.

\section{Synthesis of the Studied Cases}

The cases showed different realities in relation to the selection of IT projects, as it can be observed in Table 1.

Table 1: Comparison among the studied companies

\begin{tabular}{|l|l|l|l|l|}
\hline \multicolumn{1}{|c|}{ FACTOR } & \multicolumn{1}{c|}{ CASE A } & \multicolumn{1}{c|}{ CASE B } & \multicolumn{1}{c|}{ CASE C } & \multicolumn{1}{c|}{ CASE D } \\
\hline Industry & Focused logistics & Clothes Retail & Logistics & Manufacture \\
\hline Strategic Grid & Support & Factory & Strategic & Turnaround \\
\hline $\begin{array}{l}\text { Strategic align- } \\
\text { ment }\end{array}$ & $\begin{array}{l}\text { Strategy Execu- } \\
\text { tion }\end{array}$ & $\begin{array}{l}\text { Technology } \\
\text { transformation }\end{array}$ & $\begin{array}{l}\text { Strategy Execu- } \\
\text { tion }\end{array}$ & $\begin{array}{l}\text { Strategy Execu- } \\
\text { tion }\end{array}$ \\
\hline $\begin{array}{l}\text { Focus in the selec- } \\
\text { tion of IT projects }\end{array}$ & $\begin{array}{l}\text { Financial (costs) } \\
\text { and low risk }\end{array}$ & Strategic & $\begin{array}{l}\text { Strategic and } \\
\text { financial }\end{array}$ & $\begin{array}{l}\text { Strategic and } \\
\text { financial }\end{array}$ \\
\hline $\begin{array}{l}\text { Systematic proce- } \\
\text { dure in the selec- } \\
\text { tion of IT projects }\end{array}$ & $\begin{array}{l}\text { Does not exist. } \\
\text { Ad hoc costs cal- } \\
\text { culation process }\end{array}$ & $\begin{array}{l}\text { Although there is } \\
\text { evaluation of the } \\
\text { projects, it does } \\
\text { not always follow } \\
\text { the same sys- } \\
\text { tematic. } \\
\text { Eventually it uses } \\
\text { consultancies. }\end{array}$ & $\begin{array}{l}\text { Although there is } \\
\text { projects evalua- } \\
\text { tion, it does not } \\
\text { always follow the } \\
\text { same systematic. }\end{array}$ & $\begin{array}{l}\text { There is a Pro- } \\
\text { cedure, which } \\
\text { includes techni- } \\
\text { cal and financial } \\
\text { aspects, besides } \\
\text { business cases }\end{array}$ \\
\hline $\begin{array}{l}\text { Systematic forum } \\
\text { in the selection of } \\
\text { IT projects }\end{array}$ & $\begin{array}{l}\text { Does not exist. } \\
\text { IT projects are } \\
\text { considered as } \\
\text { part of projects } \\
\text { relative to com- } \\
\text { pany operations }\end{array}$ & $\begin{array}{l}\text { IT Committee } \\
\text { exists, composed } \\
\text { by IT area and by } \\
\text { the user areas } \\
\text { involved in the } \\
\text { projects }\end{array}$ & $\begin{array}{l}\text { IT Committee } \\
\text { exists, composed } \\
\text { by IT area and } \\
\text { Business Execu- } \\
\text { tives }\end{array}$ & $\begin{array}{l}\text { Does not exist, } \\
\text { but it is common } \\
\text { to IT team to dis- } \\
\text { cuss alternatives } \\
\text { with user areas }\end{array}$ \\
\hline
\end{tabular}

\section{Conclusions}

The objective of this paper was to analyse practices for projects ex ante evaluation and selection in companies operating in the Brazilian market and that would be classified in different quadrants of the Strategic Grid, in order to observe if any differences exist. The multiple cases study showed that there is no uniformity in the form that IT projects are selected, as previously expected. However, there was a better understanding of the involved factors, and the objectives can be considered reached.

The following considerations about the investigated propositions can be presented: 
(p1) companies classified in quadrants "Support" and "Turnaround" of the Strategic Grid should present less systematic procedures to select IT projects;

The company classified "Support" quadrant, in fact, didn't show systematic procedures, but company D ("Turnaround" quadrant) was the only one that presented systematic procedures. However, it must be stand out that this company operate in two different business areas and that such procedures were transmitted by the business area that can be classified in "Factory" quadrant. It should be noticed that projects selection concerns basically to future applications; as in the case of the "Factory" quadrant there is no expectation of new strategic IT applications; this can lead to less rigid procedures for evaluation of future applications. Meanwhile, in the "Turnaround" quadrant, there is this expectation of new IT applications that would change IT role in the future situation of the company. In this way, it makes sense that there are more systematic procedures to evaluate new IT projects. Thus, this proposition can be considered as just partially confirmed.

(p2) there is a bigger involvement of business personnel in IT projects selection in companies classified in the "Strategic" and "Factory" quadrants of the Strategic Grid;

This proposition was verified, since both in companies B and C it is clear the users' and the business management's involvement in the IT projects selection. However, it must be pointed out that company $\mathrm{D}$ also showed this characteristic, although in a less systematic way. A possible explanation would be the fact of the role of IT would be changing ("Turnaround" quadrant). Company D must be "learning" how to proceed about IT evaluation in these new conditions. Therefore, this proposition could be enlarged, to include organisations classified in the "Turnaround" quadrant.

(p3) criteria of strategic nature are more frequently used to select IT projects in companies classified in the "Strategic" and "Turnaround" quadrants" of the Strategic Grid.

The third proposition was verified for companies classified in the "Strategic" and "Turnaround" quadrants of the Strategic Grid, because both companies C and D present this characteristic. As projects selection defines future initiatives in the company, it was reasonable to expect that such fact would happen, since in these quadrants there is, by definition, strategic impact of future IT applications. Similarly to the previous proposition, this situation can also be observed in company B ("Factory quadrant).

It is interesting to notice that, unlike it was expected, this company does not adopt systematically financial criteria in the evaluations. A possible explanation would be that in this company the perspective of strategic alignment "Technology Transformation" was identified, and in this perspective, companies look fundamentally for technological leadership. Hence, there would be a larger predisposition for IT investments without many concerns to justification of financial returns. Still about company B, maybe the "instantaneous picture" of the Strategic Grid has captured a specific moment in that there were not new IT applications that could bring strategic advantages, i.e., maybe company B could be classified in the "Strategic" quadrant in a new analysis performed in a new moment.

Maybe the study has captured indications of the ways that led IT to assume today this role in organization $\mathrm{B}$. In conclusion, the concern and the dedication to compose past IT applications portfolio allowed IT applications presenting a strategic role nowadays.

Another interesting point is that, except for company D, many professionals mentioned that formal and complex procedures for evaluating IT projects would be harmful to the agility of the decisions required in turbulent markets.

In spite of the observed results showed an alignment between theory and observed practice, futures studies should contemplate a larger number of companies and/or an observation of the same companies studied in another instant in the time. 


\section{References}

Bedell, E. F. (1985). The computer solution: Strategies for success in the information age. Homewood: Dow -Jones, Irwin.

Brynjolfsson, E. \& Hitt, L. M. (1998). Beyond the productivity paradox. Communications of the ACM, 41(8), 49-55.

Carr, N.G. (2003). IT doesn't matter. Harvard Business Review, 81(5), 41-49.

Carr, N.G. (2005). The end of corporate computing. Sloan Management Review, 46(3), 67-73, Spring.

Claver, E; Gonzalez R.; Llopis, J. (2000). An analysis of research in information systems (1981-1997), Information \& Management, 37, 181-195.

Farbey, B.; Land, F. F.; Targett, D. (1995). A taxonomy of information systems applications: the benefits evaluation ladder. European Journal of Information Systems, 4(1), 41-50.

Farrell, D. (2003). The real new economy. Harvard Business Review. 81(10), 104-112, October.

Henderson, J. C.; \& Venkatraman, N. (1993). Strategic alignment: Leveraging information technology for transforming organizations. IBM Systems Journal. 32(1), 4-16.

Jiang, J. J. \& Klein, G. (1999). Project selection criteria by strategic orientation. Information \& Management, 36, 63-75.

Khalifa, G., Irani, Z., Baldwin, L. P \& Jones, S. (2001). Evaluating information technology with you in mind. The Electronic Journal of Information Systems Evaluation, 4(1), March.

Laudon, K. C. \& Laudon, J. P. (2003). Essentials of management information systems: Managing the digital firm. Upper Saddle River, NJ: Prentice Hall, 512p.

Laurindo, F. J. B., Carvalho, M. M. \& Shimizu, T. (2003). Information technology strategy alignment: Brazilian cases. In K. Kangas (Ed.), Business Strategies for Information Technology Management (p. 186199). Hershey, PA: Idea Group.

Laurindo, F. J. B. (2002). Tecnologia da Informação: Eficácia nas organizações. São Paulo: Editora Futura, 248 p.

Luehrman, T. A. (1998a). Investment opportunities as real options: Getting started on the numbers. Harvard Business Review, July-August.

Luehrman, T. A. (1998b). Strategy as a portfolio of real options. Harvard Business Review, SeptemberOctober.

Luftman, J. N., Lewis, P. R., \& Oldach, S. H. (1993). Transforming the enterprise: The alignment of business and information technology strategies. IBM Systems Journal, 32(1), 198-221.

McFarlan, W. E. (1981). Portfolio approach to information systems. Harvard Business Review, SeptemberOctober, pp. 142-150.

McFarlan, W. E.(1984). Information technology changes the way you compete. Harvard Business Review, 62(3), 98-103, May/June.

Moraes, R. O. \& Laurindo, F. J. B. (2003). Um Estudo de Caso de Gestão de Portfolio de Projetos de Tecnologia da Informação. Revista G\&P: Gestão e Produção, 10(3), 311-328.

Nolan, R. L. \& McFarlan, W. E. (2005). Information technology and the board of directors. Harvard Business Review, 83(10), 96-106, October.

Porter, M. E. (1979). How competitive forces shape strategy. Harvard Business Review, Nov-Dec, 137145.

Porter, M. E. (2001). Strategy and the Internet. Harvard Business Review, March, p.63-78.

Porter, M. E. \& Millar, V.(1985). How information gives IT competitive advantage. Harvard Business Review, Jul-Aug, 149-160. 
Rockart, J. F. (1979). Chief executives define their own data needs. Harvard Business Review, 57(2), 8192, Mar./Apr.

Tapscott, D. (2001). Rethinking strategy in a networked world. Strategy + Business, 24, 8.

Tjan, A. K. (2001). Finally, a way to put your Internet portfolio in order. Harvard Business Review, 79(2), 76-85.

Yin, R. (1991). Case study research: Design and methods. Newbury Park. Sage Pub.

Zwass, V. (1998). Foundation of information systems. Boston: Irwin McGraw-Hill.

\section{Biography}

Fernando José Barbin Laurindo is associate professor at Polytechnic School, University of São Paulo - USP (since1997). He holds Production Engineering degree (Polytechnic School of University of São Paulo). He is M.Sc. and Ph.D in Production Engineering from Polytechnic School of University of São Paulo. He also graduated in Law (University of São Paulo) and made Extension Course in Business Administration from Fundação Getúlio Vargas. He belongs to Information Technology Management Group (GTI) of the Production Engineering Department. He is the research vice-coordinator of GTI group (listed in CNPq Research Group Files). During more than ten years, he worked in Information Technology, Project and Product Management in companies of the industrial, financial and service sectors. Its main research interests are in Information Technology Management and Strategy, Competitive Strategy and Project Management.

Renato de Oliveira Moraes is an associated professor of Business Administration College (FEAD) of Minas Gerais and Federal University of Ouro Preto. He holds Production Engineering degree (Polytechnic School of University of São Paulo). He is Ph.D in Business Administration Business School of University of São Paulo. He is a researcher in the GTI group (listed in CNPq Research Group Files). He worked in many manufacturing companies, in Information Technology and Project Management areas. Its main research interests are in Information Technology Management and Strategy and Project Management. 